\title{
Model Akuntansi Kejawen "Bongkaran" (Studi Pada Paguyuban Sambung Roso Desa Sidodadi Kecamatan Garum Kab. Blitar)
}

\author{
Rumanintya Lisaria Putri', Diana Elvianita Martanti ${ }^{2}$ \\ ,Universitas Islam Balitar, Blitar \\ Emil:elvianitadiana@gmail.com
}

\section{Kata kunci: \\ Paguyuban Kejawen, Akuntansi Kejawen, Bongkaran}

\section{Keywords: Paguyuban Kejawen Bongkaran \\ Kejazwen, Accounting,}

Rumanintya Lisaria Putri1, Diana Elvianita Martanti ${ }^{2}$ Model Akuntansi Kejawen "Bongkaran" (Studi Pada Paguyuban Sambung Roso Desa Sidodadi Kecamatan Garum Kab. Blitar) Akuntabilitas: Jurnal IlmuIlmu Ekonomi, 13(1),2020, $71-80$

https://doi.org/10.35457/aku $\underline{\text { ntabilitas.v12i1.720, }}$

\begin{abstract}
ABSTRAK
Tujuan penelitian ini adalah mengetahui model akuntansi kejawen pada paguyupan Sambung Roso Desa Sidodadi Kecamatan Garum Kab. Blitar, Paguyuban kejawen merupakan paguyuban yang berhubungan kental dengan adat budaya jawa, aktivitas apapun pada paguyuban tersebut sangatlah erat dengan budaya lokal jawa. Salah satu aktivitas yang ada dalam paguyuban yaitu aktivitas ekonomi, selain demi kesejahteraan anggotanya, aktivitas ekonomi sanagt bermanfaat dan berguna bagi kelangsungan jalannya segala macam bentuk kegiatan yang ingin diadakan sebuah paguyuban. Sesuatu yang berhubungan dengan ekonomi dan uang pastilah erat kaitannya dengan sistem akuntansi yang pada dasarnya dalam segala macam aktivitas dalam proses pengelolaan keuangan akan sangat membutuhkan sistem akuntansi dalam menjalankannya. Penelitian ini ditujukan untuk melihat model proses pengelolaan keuangan dengan konsep akuntansi kejawen yang disebut "bongkaran" pada paguyuban kejawen yang bernama paguyuban kejawen sambung roso yang berada di kecamatan garum. Penelitian ini dalam prosesnya menggunakan teknik deskristif kualitatif dengan menggunakan tiga teknik dalam pengumpulan data, yakni observasi, wawancara, dan analisis data. Sedangkan dalam proses analisis data dalam penelitian ini yaitu pemahaman materi, pegumpulan data, reduksi data, dan penarikan kesimpulan. Hasil penelitian ini menilai konsep bongkaran sangat membantu dalam menyejahterakan anggota dan efektih dalam mendapatkan kas untuk paguyuban kejawen sambung roso.
\end{abstract}

\section{ABSTRACT}

The purpose of this study is to find out the Kejawen accounting model in Paguyuban Sambung Roso of Sidodadi Village, Garum District. Blitar, Paguyuban Kejawen is a community closely related to Javanese culture, almost all activities in community (paguyuban) is very close to Javanese local culture. One of the activities in Paguyuban is economic activity, in addition to welfare its members, economic activity is very useful for the continuity of all kinds activities that want to be held by a community (Paguyuban). Something related to economics and money must be closely related to the accounting system which basically all kinds of activities in the process of financial management will need an accounting system to run. This study aimed to look at the financial management process model with the Javanese accounting concept called "bongkaran" in the Javanese community (Paguyuban) called Paguyuban Kejawen Sambung Roso in Garum sub-district. This research uses qualitative descriptive techniques using three techniques in data collection, namely observation, interviews, and data analysis. While the process of analyzing data in this study, namely understanding material, data collection, data reduction, and drawing conclusions. The results of this study assess the concept of bongkaran is very helpful in the welfare of its members and effective in getting cash for Paguyuban Kejawen Sambung Roso. 


\section{PENDAHULUAN}

Akuntansi saat ini tidak dapat dipungkiri bahwa sudah masuk pada segala macam bidang atau dimensi yang berkaitan dengan keuangan atau ekonomi mengglobal, bahwa dapat dipastikan saat itu juga bidang akuntansi pasti ikut masuk dalam bidang - bidang yang bahkan tidak mungkin akuntansi ada disitu. Pengertian akuantansi menurut Thomas Sumarsan (2013 : 1) menjelaskan bahwa akuntansi adalah suatu seni untuk mengumpulkan, mengidentifikasi, mengklasifikasi, mencatat transaksi, serta kejadian yang berhubungan dengan keuangan, sehingga dapat menghasilkan informasi yaitu laporan keuangan yang dapat digunakan oleh piha pihak yang berkepentingan.karena akuntansi merupakan bagian dari bidangbidang ekonomi tersebut. Metode pencatatan, penggolongan, analisa dan pengendalian transaksi serta kegiatan-kegiatan keuangan, kemudian melaporkan hasilnya. Kegiatan akuntansi diantaranya :

1. Pengidentifikasian dan pengukuran data yang relevan untuk suatu pengambilan keputusan.

2. Pemrosesan data yang bersangkutan kemudian pelaporan informasi yang dihasilkan.

3. Pengomunikasian informasi kepada pemakai laporan.

Kita tidak selalu bisa memaksakan diri untuk menerapkan praktik akuntansi yang selama ini diadopsi dari luar negeri. Penyebabnya karena dengan alasan bahwa akuntansi yang diadopsi dari luar negeri tidak dapat menyelesikan masalah masalah yang bersifat kearifan lokal. Praktik akuntansi yang dijalankan berdasarkan dari adopsi luar negeri hanya sesuai dengan masalah seputar wilayah di luar negeri tersebut saja. Prosedur, teknik, dan metode pencatatan transaksi keuangan dilakukan untuk mencapai tujuan pelaporan keuangan yang telah ditetapkan yang sesuai dengan wilayah luar negeri tersebut. Salah stu faktor lingkungan yang mempengaruhi bentuk praktik akuntansi yang jarang terfikir oleh kita adalah faktor budaya lokal dan agama.

Budaya dapat didefinisikan oleh Kuntowijoyo (2006:, 3), bahwa adalah hasil karya cipta (pengolahan, pengerahan, dan pengarahan terhadap alam) manusia 
dengan kekuatan jiwa (pikiran, kemauan, intuisi, imajinasi, dan fakultas - fakultas rohaniah lainnya) dan raganya yang menyatakan diri dalam berbagai kehidupan (ruhaniah) dan penghidupan (lahiriah) manusia sebagai jawaban atas segala tantangan, tuntutan dan dorongan dari interen diri manusia, menujua arah terwujudnya kebahagiaan dan kesejahteraan (spiritual dan material) manusia, baik individu maupun masyarakat. Budaya lokal dan agama suatu wilayah akan memberikan gaya berpraktik akuntansi yang berbeda. Gagasan-gagasan yang muncul di balik praktik akuntansi yang dipengaruhi oleh budaya lokal suatu wilayah jelas akan berbeda dengan praktik akuntansi yang dipengaruhi budaya lokal dari wilayah yang lain. Praktik akuntansi yang berjalan karena pengaruh budaya jawa misalnya, jelas akan memunculkan gagasan-gagasan di balik praktik akuntansi tersebut dengan sifat-sifat akatau karakteristik alamiah dari jawa.

Akuntansi telah berkembang secara dinamis, mulai dari yang paling sederhana, yang memandang akuntansi sebagai sistem pencatatan, sampai dengan yang paling mutakhir yang memandang akuntansi sebagai sistem informasi yang sarat dengan penggunaan teknologi. Perkembangan akuntansi tersebut dipengaruhi oleh beberapa faktor diantaranya adalah kondisi budaya, ekonomi, hukum, sosial, dan politik dimana akuntansi itu berkembang. Masyarkat jawa tergolong sangat kuat dan kental dalam melestarikan segi budaya berkeraifan lokalnya, mereka sangat kuat dalam mempertahankan nilai-nilai tradisional yang bersumber dari nenek moyang atau leluhur pulau jawa.

Penjelasan berikut dibuktikan bahwa dengan adanya konsep baru pada sistem ekonomi tradisional yang di praktikan oleh masyarakat, khususnya dalam bahasan ini pada paguyuban kejawen yang bernama sambung roso. Paguyuban kejawen yang berada di kecamatan garum ini merupakan paguyuban yang memiliki visi dan misi salah satunya yaitu tetap melestarikan budaya jawa. Anggota pada paguyuban ini terdiri dari laki-laki dan perempuan paruh baya, selain itu ada juga beberapa pemuda dan pemudi yang ikut serta juga menjadi anggota paguyuban sambung roso tersebut. Dalam mencapai tujuan dari paguyuban sambung roso ini dalam melestarikan budaya banyak mengadakan aktivitas-aktivitas atau kegiatan- 
kegiatan yang berhubungan dengan budaya jawa khususnya. Selain itu pada paguyuban kejawen sambung roso ini juga melakukan aktivitas ekonomi demi kesejahteraan anggota dan dapat berjalannya paguyuban tersebut.

Salah satu kegiatan atau aktivitas ekonomi yang dilaksanakan oleh paguyuban kejawen sambung roso ini bernama "bongkaran". Paguyuban kejawen sambung roso mempunyai konsep bongkaran ini yang dapat digunakan untuk mendanai kegiatan kegiatan paguyuban dan dapat menguntungkan bagi anggota denga perhitungan tertentu yang sebelumnya masing-masing anggota wajib menyimpan uang pada bendahara paguyuban yang nantinya akan menjadi tolok ukur banyaknya bongkaran yang didapat anggota dan kas yang didapat paguyuban kejawen sambung roso tersebut.

Penelitian ini ditujukan untuk mengetahui bentuk model dari konsep bongkaran yanga ada pada paguyuban kejawen sambung roso, yang pada dasarnya sebagai salah satu pendana bagi kegiatan - kegiatan paguyuban dan dapat dikatan sebagai tabungan demi menyejaterakan anggota paguyuban pula. Selanjutnya hasil penelitian ini dapat memberi manfaat baik dalam kegiatan praktisi maupun akademik. Dari segi akademik diharapkan dapat memberi kontribusi ilmiah dalam rangka pengembangan ilmu pengetahuan mengenai model konsep akuntansi kejawen.

\section{METODE PENELITIAN}

Penelitian kualitatif adalah prosedur penelitian yang menghasilkan data deskriptif berupa kata - kata tertulis atau lisan dari orang - orang dan perilaku yang dapat diamati, hal ini dikemukakan oleh Taylor dalam Moleong (2010:4). Usaha tersebut dilakukan dengan menggunakan metode- metode ilmiah, dengan demikian penelitian yang dilaksanakan tidak lain utnuk memperoleh data yang telah teruji kebenaran ilmiahnya. Penelitian ini menggunakan pendekatan kualitatif yang menghasilkan data secara deskriptif berupa kata-kata tertulis atau lisan dari orangorang dan perilaku yang diamati, terdiri dari wawancara yang mendalam dan terbuka yakni data yang diperoleh terdiri dari kutipan langsung dari orang-orang 
tentang pengalaman, pendapat, dan pengetahuan. Seperti yang dikatakan oleh Nazir (2011:52) yaitu penelitian deskriptif dipilih karena tertuju pada pemecahan masalah yang ada pada masa sekarang yang mencakup teknik deskriptif, diantaranya adalah penyelidikan dengan tehnik survei, interview, observasi atau dengan teknik test.

Pada sistem wawancara sangatlah penting dalam pemilihan narasumber atau informan yang patut dipercaya dan berpengalaman dalam pembahasan penelitian, dikarenakan penelitian ini membahas model konsep bongkaran pada paguyuban kejawen sabung roso, maka dalam hal ini saya memilih informan yang mewakili dari anggota paguyuban yakni dan Ibu Lasemi dan Ibu Narwati. Selain itu seperti yang dikatakan di atas, pada penelitian ini menggunakan analisis dengan pendekatan kualitatif, oleh karena itu data yang telah dikumpulkan dan telah di cek keabsahannya serta dinyatakan valid, dapat diproses melalui langkah - langkah yang bersifat umum, yakni:

1. Reduksi data yakni data yang diperoleh di lapangan ditulis dalam bentuk uraian atau laporan yang terperinci. Laporan tersebut direduksi, dirangkum, dipilih hal hal yang pokok, difokuskan pada hal -hal yang penting, dicari tema dan polanya.

2. Mengambil kesimpulan dan verifikasi, yakni data yang telah terkumpul telah direduksi, lalu dicari maknanya kemudian dilakukan penarikan kesimpulan akhir.

\section{HASIL PENELITIAN DAN PEMBAHASAN}

Paguyuban kejawen sambung roso merupakan paguyuban yang berdiri pada tahun 1995. Paguyuban ini terbentuk Awal mulanya ketika terbentuknya klenigan masyarakat sekitar menyebutnya yang artinya adalah komunitas kesenian karawitan kecil-kecilan yang anggotanya terderi dari pecinta-pecinta budaya dan segala ilmu pengetahuan tentang jawa oleh Martopangrawit, (1975 1-2). Berjalan selama sekitar satu bulan latihan dan petemuan yang terdiri dari empat kali berkumpul tersebut, seiring itu calon-calon anggota baru yang sepaham dengan anggota lainnya dalam memandang tentang jawa semakin bertambah jumlahnya, karena semakin bertambah sehingga pemain gamelanpun banyak sekali yang tidak mempunyai 
kesempatan untuk ikut memainkan alat musik jawa atau gamelan tersebut. Sehingga saat itu terbentuklah obrolan-obrolan santai tentang ilmu pengetahuan jawa, filososfi jawa, kebudayaan-kebudayaan jawa yang lainnya. Kondisi demikian berjalan selama kurang lebih dua tahunan disertai terus bertambahnya anggotaanggota baru yang ikut bergabung. Tahun 1995 seluruh anggota dari komunitas karawitan tersebut memutuskan untuk membentuk atau mendirikan sebuah paguyuban kejawen dengan dasar beberapa hal yakni antara lain karena cukup banyakknya anggota yang suka dengan budaya jawa, selain itu anggota-anggota tersebut memiliki visi dan misi yang sama atau sependapat yakni ingin melestarikan budaya jawa bersama-sama.

Walaupun hanya sekedar paguyuban kejawen tetapi paguyuban ini pun berstruktur layaknya organisasi-organisasi umum lainnya. Paguyuban kejawen sambung roso dalam menjalankan kebijakan-kebijakan atau aktivitasnya dikelola oleh pengurus yang terdiri dari seorang ketua, wakil ketua, sekertaris I dan II, bendahara I dan II, dan penasehat. Para pengurus ini diberi tugas untuk bertanggung jawab penuh atas kepengurusan kepentingan organisasi, menjalankan tugas dan kewajibannya dalam melaksanakan kegiatan. Seperti halnya penjelasan yang diberikan oleh Ibu Lasemi:

"Yo kumpulan kuwi panggah enek ketuane mbak, lek ndak enek bubrah no ra enek seng ngatur, yo koyok biasa ketua, wakil, terus seng tukang nyateti, seng tukang nyekel duwit karo nyateti bongkaran kuwi mbak biasane, panggah yo enek ngono kuwi mbak, sak weruhku ngono".

Penjelasan dari masing-masing pengurus sebagai berikut, tugas dari seorang ketua adalah memimpin dan membimbing seluruh anggotanya untuk melakukan kegiatan dalam tugasnya masing-masing. Tugas dari wakil ketua adalah membantu kaetua jika ketua mendapatkan halangan sehingga tidak bisa mengikuti kegiatan, selain itu wakil ketua juga bertanggung jawab atas pengawasan dan pembimbingan terhadap anggota. Tugas dari sekertaris I adalah mencatat segala hal yang mengandung ide, pokok pikiran atau kegiatan-kegiatan yang akan dilaksanakan seluruh anggota. Tugas sekertaris II membantu pencatatan sekertaris I. dan tugas dari bendahara I adalah mencatat laporan keuangan hasil dari kegiatan Paguyuban 
Semut Ireng yang menghasilkan dana. Sedangkan tugas dari Bendahara II adalah mencatat khusus uang kas dari anggota. Karena memang ada perbedaan uang kas dari kegiatan dan uang kas dari diri pribadi anggota paguyuban kejawen sambung roso tersebut. Tugas penasehat yaitu seseorang yang dianggap tua dalam segi ilmu pengetahuannya tidak hanya karena umurnya, yang mempunyai tugas memberikan petuah-petuah serta mendatangkan narasumber jawa yang nantinya akan memberikan pemantik semangat pada anggota-anggota paguyuban saat ada kegiatan yang bertujuan melestarikan budaya kejawen atau jawa.

Bendahara dalam paguyuban kejawen ini juga berperan peting dalam pelaksanaan atau jalannya kegiatan paguyuban karena bendaharalah yang tahu sumber- sumber pendanaan serta konsep perhitungan secara akuntansi sebatas yang mereka ketahui dan yakini. Konsep aktivitas ekonomi pada paguyuban kejawen sambung roso ini merupakan konsep secara akuntansi umum yakni semacam akuntansi simpan pinjam tetapi hanya saja disini menggunakan sistem konsep alur perhitungan yang menggunakan istilah-istilah jawa serta beberapa menggunakan perhitungan sesuai yang mereka ketahui saja. Sebagai salah satu contoh dari aktivitas ekonomi pada paguyuban kejawen sambung roso ini adalah konsep bongkaran.

Konsep bongkaran merupakan konsep dimana anggota menyimpan uang pada bendaharan yang nantinya dinjamkan juga kepada anggota paguyuban tersebut, dan pada akhirnya akan dihitung pada periode satu tahun sekali. Seperti halnya yang dikatakan langsung oleh bendahara dari paguyuban kejawen sambung roso tersebut, Ibu Narwati:

"Jenenge ki uduk bongkar bunga mbak, tapi bongkaran kuwi maksud'e ngitung kabeh jumlah andil ditambah penyauran utang trus di itung gek dibagikan dadi SHU ( Sisa Hasil Usaha )".

Setelah melakukan penelitian, yang hasilnya mendeskripsikan tentang konsep dari bongkaran yang oleh peneliti digambarkan dalam model seperti berikut: 


\section{Gambar 1.}

Model Konsep Bongkaran Pada Paguyuban Kejawen Sambung Roso

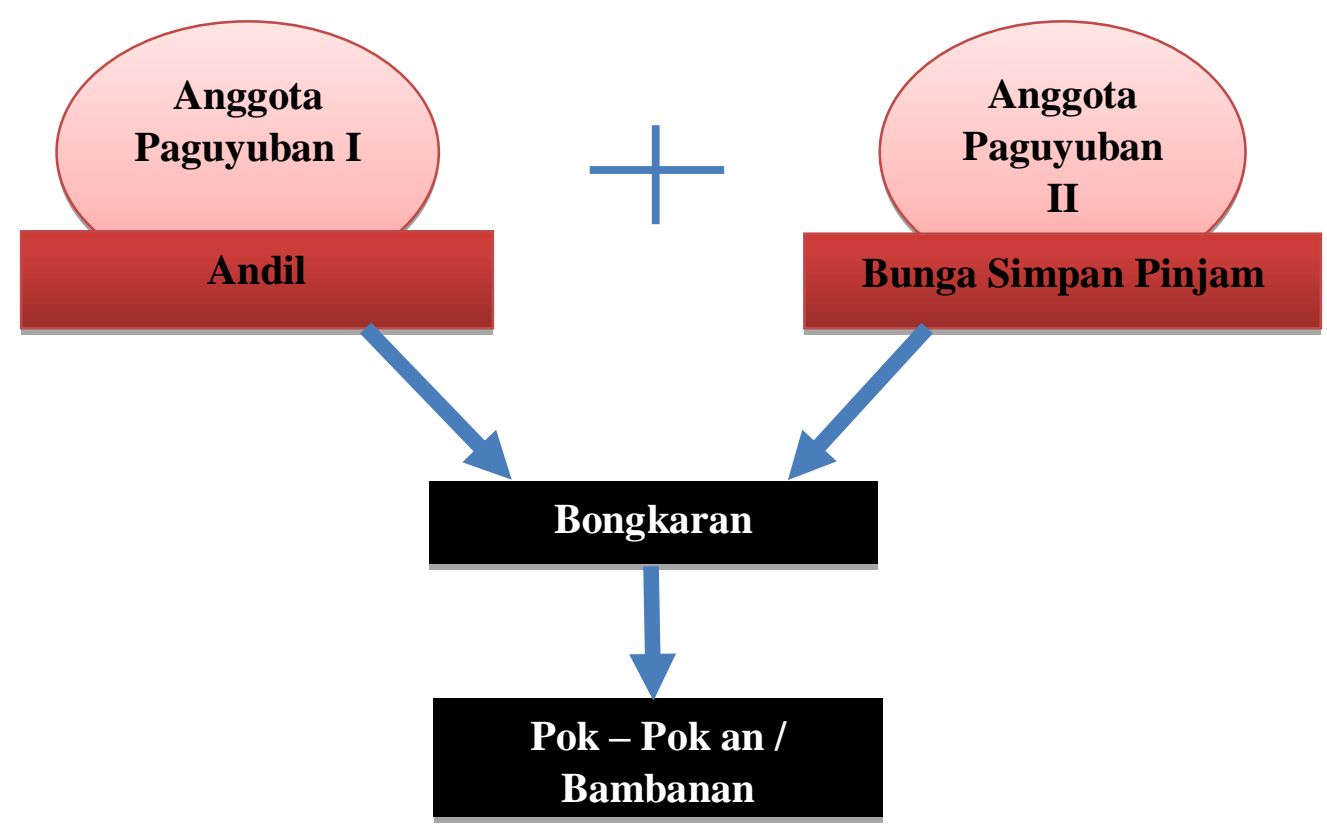

Sumber: Peneliti 2020

Gambar model diatas dapat dijelaskan dengan penjelasan sebagai berikut: anggota pertama dari paguyuban kejawen ini memberikan modal awal yang dalam paguyuban bernama andil, guna aktivitas ekonomi agar dapat berjalan, selanjutnya anggota paguyuban dua meminjam kembali kumpulan modal awal dari anggota angota yang memberikan uang untuk modal awal dimaksudkan agar ativitas ekonomi atau perputaran uang dapat berjalan, selanjutnya meminjam uang tersebut akan dikenai bunga sebesar $5 \%$ sesuai kesepakatan bersama (bunga simpan pinjam), sehingga tidak ada yang merasa terpaksa dan merasa dirugikan karena peraturan peraturan dalam konsep bongkaran inipun suadah di rumuskan secara bersama sama tentunya juga dengan persetujuan bersama - sama. Selanjutnya bongkaran didapat dari modal awal atau simpanan awal ditambahan dengan hasil bunga yang didapat dari pinjaman - pinjaman akibat aktivitas ekonomi tersebut yang dibagikan sesuai jumlah nama anggota yang memberikan modal awal. Akhirnya dibagikannya sisa hasil usaha atau keuntungan dari aktivitas ekonomi tersebut dan dari jumlah keseluruhan di ambil 5\% untuk kas paguyuban kejawen sambung roso tersebut. Dan 
$10 \%$ untuk dibagi seluruh pengurus. Pernyataan tersebut didukung oleh penjelasan dari bendahara paguyuban kejawen sambung roso (Pok - pok an / Bambanan), Ibu Narwati:

"Terus perhitungane hasil dari bongkaran itu hasilnya sari semua perolehan uang 5 $\%$ buat uang kas paguyuban terus $10 \%$ untuk pengurus nanti dibagi sendiri berapa besarnya untuk pengurus paguyuban mbak gitu".

Konsep dari bongkaran ini berdasarkan penelitian dapat di katakana sangat menguntungkan bagi anggota, karena dapat dikatakan sebagi tabungan yang dapat diambil satu tahun sekali dan tidak memberatkan anggota sama sekali karena dlam memberi modal awal atau simpanan awal, anggota hanya melakukannya satu kali saat setiap setelah bongkaran dalam satu tahun, selain itu dapat dikatakan konsep ini juga sangat menguntungkan dan bermanfaat bagi paguyuban kejawen sambung roso sendiri karena cukup membantu menambah uang kas guna pendanaan pendanaan kegiatan paguyuban sendiri. Walaupun pada sejarah awalnya bongkaran ini memang dimaksudkan untuk mencari dana kas yang terus bisa mengalir, dengan catatan tetap mengedepankan kesejahteraan anggota dengan kata lain anggota tidak merasa dirugikan dan terbebani melainkan merasa sangat terbantu dan diuntungkan dengan adanya bongkaran ini.

\section{KESIMPULAN}

Kesimpulan bahwa pada paguyuban kejawen di kecamatan garum yang bernama sambung roso telah mempunyai salah satu aktifitas yang penting yaitu aktifitas ekonomi salah satunya menggunakan konsep bongkaran yaitu menggunakan konsep perhitungan akuntansi berbasi kearifan lokal atau sering disebut dengan akuntansi kejawen, karena banyak menggunakan istilah jawa dan perhitungannya pun hanya sebatas pengetahuan dan keayakinan dari hasil musyawarah anggota - anggota paguyuban kejawen sambung roso tersebut. Serta daoat di simpulkan bahwa berdasarkan penjelasan model konsep bongkaran dan kutipan wawancara bersama perwakilan anggota dari paguyuban tersebut diatas, dapat dikatakan bahwa konsep ini cukup membantu, menguntungkan dan 
bermanfaat bagi anggota - anggota paguyuban maupun bagi paguyuban kejawen sambung roso tersebut.

\section{DAFTAR PUSTAKA}

Kuntowijoyo. 2006. Budaya dan Masyarakat. Yogyakarta: Tiara Wacana.

Sumarsan, Thomas. 2013. Perpajakan Indonesia (Vol 3). Jakarta: PT. Indeks

Sugiri, Slamet dan Bogat Agus Riyono. 2008. Akuntansi Pengantar 1. Yogyakarta: STIM

Surakhmad, Winarno. 1983. Pengantar Penelitian Ilmiah, Dasar, Metode, Teknik. Bandung: Transito

Geertz, Clifford. 1989. Abangan, Santri, Priyayi dalam Masyarakat Jawa, Jakarta: Pustaka Jay

Martopangrawit. 1975. Pengetahuan Karawitan I. Surakarta: ASKI Surakarta.

Soedarjono, Harjo. 2007. Pemikiran Religius Budaya Spiritual Penghayat Kepercayaan Kejawen. Kejawen: Jurnal Kebudayaan Jawa.

Sugiono. 2010. Metode Penelitian. Bandung: CV Alfabeta.

LJ, Moleong, Taylor. 2010. Metode Penelitian Kualitatif. Bandung: Remaja Rosda Karya

Moh Nazir. 2011. Metode Penelitian Cetakan 6. Bogor: Ghalia Indonesia 